\title{
Research on Taxation Policy to Promoting SMEs' Technological Innovation
}

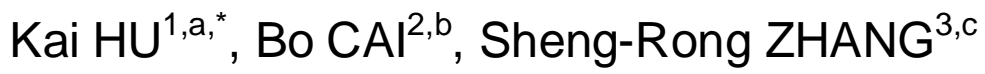 \\ ${ }^{1,2,3}$ College of Economics and Management, Jiangxi Agricultural University, Nanchang \\ 330045, China \\ acarl-hu@163.com, bcaibofuture@yahoo.com.cn, cjxndzhangshengrong@tom.com \\ *Corresponding author
}

Keywords: SMEs, Technological innovation, Taxation policy.

\begin{abstract}
Small and medium enterprises(SMEs) are the significance component of national technology innovation system. Government should encourage SMEs engaging in technological innovation through innovation policy. Taxation policy is one of the widely used policy instrument by most countries. Resources can be allocated more efficient guided by taxation policy. Compared the OECD's taxation policy, analyzed the disadvantages of Chinese taxation policy from three aspects, which are orientation deviation, objects deviation and insufficient support for venture capital, put forward suggestions to consummate the taxation policy.
\end{abstract}

\section{Introduction}

With the rapid development of economy as well as establishment of socialist market economic system in China, SMEs occupy more and more important position in national economy. SMEs have become important force to promote economic and social development in China, which created about $60 \%$ GDP, $50 \%$ tax, $70 \%$ exports, nearly $80 \%$ jobs in cities and towns. Development of SMEs is related to economy, politics, people's livelihood, employment, social stability and other aspects.

Meanwhile, we must realize that global economic growth is weak after international financial crisis, world's major economies; especially in Europe and the United States are still mired in economic crisis, which cause SMEs face more complex environment and threaten. At present, SMEs of China are facing lots of problems such as shrinking market, production costs rising, financing difficulties, etc.

SMEs must strength technological innovation to get rid of business distress and enhance competitive ability. In fact, SMEs are not only important part of country economics and social development, but also important part of national technological innovation. Technological SMEs (Tech-SMEs) are the most dynamic and vigorous main body engaging in innovation. Now, $65 \%$ of the patents, $75 \%$ of technological innovation and $80 \%$ of new products in China are accomplished by SMEs [1].On the other hand, innovation has the characteristics such as high risk, large investment and externalities, which inevitably caused market failure [2].Hence, governments around the world have formulated a series of innovation policies to encourage SMEs engaging in technological innovation. For example, both The United States and Japanese established a perfect service system to support technological innovation for SMEs [3, 4].

Innovation policy includes a series of policies put forward by government for encouraging enterprise engage in technological innovation, which include fiscal subsidies, financing support, taxation policy, government procurement, intellectual property rights (IPR) protection policy and so on[5]. Among all these policies, taxation policy is widely used by many countries, as an unique policy instrument of easily to operate and low implement administrative cost. Influence of taxation policy to entrepreneurial behavior is mainly embodied through income tax. Cullen et al. (2002) pointed out that low income tax rate can enhance the ability and motivation of entrepreneurs taking risks, thereby stimulate entrepreneurs carrying on independent innovation [6]. In many countries, 
taxation policy is the most important way of government support science and technology(S\&T) research and industrialization, unlikely direct investment in S\&T, it is an indirect investment way.

\section{Connotation of Taxation Policy to Promoting SMEs' Technological Innovation}

Taxation is an important part of national fiscal and taxation policy, its main function is to adjust social production, distribution, exchange and consumption. Taxation is one of the important means of government macro-control, that can correct market failure related with enterprise technological innovation, hence encourage enterprise engage in innovation [7].Taxation policy to promoting enterprise technological innovation mainly include duty-free to research institutions, reduce and return tax for commercial R\&D and some specific high-tech industry,etc.

Both taxation policy and direct subsidies are the instruments that government used to support enterprise technological innovation, but they also have different characteristics. Direct subsidy mainly occurs before the process of technological innovation, its advantage is easily to determine supporting amount and can draw up a budget in advance, but it also may cause substitution effect to enterprise's R\&D input, and possible cause discrimination and unfairness [8]. Taxation policy mainly occurs after the process of technological innovation, can allocate resources more efficiently through market mechanism, hence can be universal and without discrimination, therefore the policy instrument are generally adopted by governments around the world [9].

Can taxation policy achieve the goal of promoting enterprise increase investment on technological innovation? In the other word, how the efficiency of taxation policy is? Scholars studied the relation between tax incentives and enterprise's R\&D expenditure, Dagenais et al. (1997) found that $\$ 1$ government give up, private $R \& D$ expenditure will increase $\$ 0.95$, other scholars also discovered that tax incentives can increase enterprise's R\&D expenditure[10].

\section{Taxation Policy to Promoting Innovation in Other Countries}

Since 1990s, member countries of Organization for Economic Cooperation and Development (OECD) have established a series of taxation policies to promoting technological innovation; mainly include tax relief, accelerated depreciation, $R \& D$ expense deduction, specific reserve system, etc. At present, most countries in the world provide various tax preferences to enterprise.

\section{Tax Relief}

Tax relief refers to deduce enterprise's $R \& D$ expenditure from the taxable income, amount of deduction are determined both by totally amount and growth rate of enterprise's R\&D expenditure. The advantages of this way are high transparency, take effect quickly, and reduce business cost directly, so the taxpayer can receive direct benefit. Tax relief has many forms in USA. Enterprises are allowed to offset the taxable income according to $10 \%$ of equipment investment to encourage enterprise purchase equipment for technological innovation, $25 \%$ of the amount above average $R \& D$ expenditure of last three year, and $20 \%$ of $R \& D$ expenditure that enterprise entrust university engaged in basic research project. In Germany, enterprise introduces advanced technology patent from abroad, not only tax can be exempted, but also can receive 3\% reward subsidies [11].

\section{Accelerated Depreciation}

Accelerated depreciation refers to extract more depreciation from the fixed asset at the initial period of the durable years, and then reduce year by year. Although the total tax is equal of the two deprecation method, which are accelerated depreciation and straight-line depreciation, but as a result of accelerated depreciation, enterprise tax burden is less in the early stage and more in the later stage, that can be regard as interest-free loans provided by government. Many countries implement $100 \%$ or higher accelerated depreciation rate for machinery equipment and real estate.

In American, depreciation period of machinery equipment used for R\&D is 3 years, depreciation period of machinery equipment used for production is 5 years, and depreciation period of software 
used for S\&T development is 2 years. Korea allows enterprise select either tax deduction or accelerated depreciation for equipment investment of its $R \& D$ institutions, tax deduction according to $5 \%$ of investment amount (10\% for domestic equipment), or accelerated depreciation at rate of $50 \%$ ( $70 \%$ for domestic equipment). Britain, Denmark and Ireland allow enterprise offset the purchase expenses of building and machines related with $R \& D$ in the current year [12]. In Japan, government provides large tax preference as equipment depreciation to SMEs that invest in new technology and equipment so as to save energy or use new energy [13].

\section{R\&D Expense Deduction}

$R \& D$ expense deduction refers to the $R \& D$ expense related with develop new products, new technology, new production process can be additional deducted.

In Australia, beside 125\% offset of enterprise's R\&D expense, the incremental portion of R\&D expense can be offset at $175 \%$. In Britain, $R \& D$ expense can be offset at $125 \%$ for large enterprise and $150 \%$ for SMEs [14]. For encouraging university-industry cooperation in Hungry, R\&D expense will be offset at $300 \%$ (ordinary is $100 \%$ ) if enterprise R\&D center built in university.

Many countries also introduce tax deduction method of R\&D backward and forward deduction, which means allow enterprise offset future earnings according to $R \& D$ expense, in order to reduce future taxable income, or offset earnings of past years and return taxes that had already paid. Tax law of America regulates if enterprise occurs loss or not pays income tax, amount of tax exemption and $R \& D$ expense deduction can be offset backward three years and forward seven to fifteen years; while in Canada respectively is three years and ten years

\section{Specific Reserve System}

Specific reserve system is aimed to reduce investment risk of Hi-tech enterprise and increase innovation fund. Technology development reserve system of South Korea allows enterprise draw technology development reserve according to $3 \%$ of the total income(4\% of the technology intensive industries) to increase the fund of technological innovation, which regarded as loss before actual investment, and can be used for technological innovation in the future three years. Japan allows computer manufacturers to draw technology reserve according to $10 \%$ of sales revenue [15]. Singapore allows enterprise that has been approved to draw scientific research reserve according to $20 \%$ of taxable income. Germany allows enterprise to draw different reserves, such as depreciation reserves, bad debt reserve, venture capital reserves, loss reserve, etc.

\section{Major Defects of Current Taxation Policy of China}

\section{Deviation in the Target of Taxation Policy}

According to the preferential way, taxation policy can be divided into direct and indirect. Direct preferential way include tax exemptions, reduction and preferential tax rate, it is primarily aimed at the enterprises which have obtained the benefit of technological innovation, but those enterprises which are still on the process of innovation can't enjoy a discount. The ex post preferential way has no significance help to guide enterprise beforehand engaged in R\&D activities. Indirect preferential way include pre-tax deduction, investment tax credit, refund after collection, accelerated depreciation and so on, can provide appropriate subsidies to the enterprise which is on the innovation process. This kind of preferential is conducive to formulate effective market mechanism, and can be fairer. Most developed countries mainly adopt indirect preferential way [16, 17].

Taxation policies of China give priority to direct preferential way and take indirect preferential way as supplement. According to statistics, the proportion of direct preferential is $62.83 \%$.

\section{Deviation in the object of taxation policy}

Current taxation policy implemented in China stipulated relatively strict audit standard or had a specific orientation. On the one hand, strict audit standard and high threshold may cause many SMEs can't enjoy the discount. For example, Law of Corporate Income Tax regulate startup 
investment of venture capital firm can be deducted according to a certain percentage, but the invested enterprises must meet the double standards of SMEs and Hi-Tech enterprises, especially after the adoption of new standard of Hi-Tech enterprises, further improve the threshold of the preferential policy[18]. On the other hand, lots of taxation policies are a kind of preferential system for particular objects, which easily cause rent-seeking effect. For example, the No 34 Announcement of National Audit Office posted in 2011 pointed out 17 not qualified enterprises been identified as Hi-Tech enterprises by the Acknowledging and Management Agency in nine provinces, resulting in a tax loss of 2.666 billion yuan[19].

\section{Insufficient support for venture capital}

Common problem for SMEs' technology innovation is the lack of funds; the successful experience of Silicon Valley shows the outstanding contributions of venture capital. For numerous SMEs in China, especially for Tech-SMEs, it is the key for enterprise sustained innovate whether the enterprise can introduce external capital in the case of insufficient of endogenous capital. For this reason, government should lead venture capital to participate in SMEs' technology innovation through effective tax system. For example, The United States launched a series preferential tax policies to encouraging long-term risk investment to Tech-SMEs, Tax Act enacted in 1978 reduced the capital gains tax rate from $49.5 \%$ to $28 \%$, furthermore reduced to $20 \%$ in 1981 [20]. China has no specific preferential tax policies and regulations to venture capital [21].

\section{Suggestion for improvement of taxation policy to SMEs' technology innovation}

Taxation policy of S\&T has not long history in China; there are still some institutional defects. Government should reform taxation policy, provide more support for SMEs' technology innovation.

\section{Enlarging the proportion of indirect preferential}

Orientation of policy design has important influence to policy's performance. Direct preferential of taxation policy is ex post, essentially is a kind of result-oriented policy tool, can reward those enterprise which have already obtained the benefit of technological innovation, the so-called "the icing on the cake". While indirect preferential of taxation policy is essentially a kind of process-oriented policy tool, can provide appropriate subsidies to the enterprise which is on the innovation process, the so-called "provide timely help". Obviously, "provide timely help" is more meaningful than "the icing on the cake" for SMEs. Therefore China should optimize structure of taxation policy, enlarge the proportion of indirect preferential such as accelerated depreciation, R\&D expense deduction, etc.

\section{Transformation from preferential system to generalized preference system}

There are many disadvantages to identify the objects of taxation policy according to certain criteria, such as regional (whether in Hi-Tech Development Zone), industry (whether is the national key industry, such as software, integrated circuit and pharmaceutical, etc.), pattern of ownership (state-owned, private and foreign capital), which may cause numerous SMEs can't enjoy the preferential policy, are not conducive to SMEs' technological innovation. We should transform the preferential system to generalized system of preference. Regardless of SMEs' identity and attribute, government should provide appropriate tax preferences once SMEs engaged in technological innovation. In fact, this is also a kind of process-oriented policy design.

\section{Decreasing the financial difficulties of SMEs}

On the one hand, government should enlarge tax preferences for risk investment; promote the development of venture capital. For encouraging venture capital, solve the problem of financing difficulties of SMEs' technology innovation, China should increase the supply of taxation policy for venture capital, furthermore consummate the existing system design for startup capital, reduce the threshold of venture investment. Government should deduct taxable income amount of venture 
investor according to a certain proportion of its investment amount when venture investor invest to qualified Tech-SMEs.

On the other hand, government should increase taxation policy instrument, introduce new policy instruments that widely used in developed countries such as technical development reserve, allow SMEs set up various reserves according to a certain proportion of revenue, which include risk reverse, technical development reserve, new product trail production reserve, loss reserve and so on, expand corporate endogenous funding, improve corporate ability against risk.

\section{Summary}

Reform of taxation policy of S\&T is complicated. The most important in reform of tax system is to clearly identify the overall principle and policy's orientation, integrate result-oriented and process-oriented, combine foreign advanced experience and concrete practice of China, so that Chinese taxation policy will be more effectively to promote corporate technological innovation.

\section{Acknowledgement}

This research was financially supported by the National Science Foundation (70113021) and Jiangxi Social Science Planning Program (08YJ105)

\section{Reference}

[1] Xiaohong Chen, Honglie Ma. Impact of tech-innovation on growth: are high-tech SMEs different from non-high-tech SMEs? [J] Studies in Science of Science, 2012, 30(11):1749-1760.

[2] Kai Hu, Jidong Yin. Research on Constitute and Mechanism of Regional Innovation System [J] Science and Technology Management Research, 2007, (7):99-101.

[3] Meiyi Yang. International Comparison of Service System for SMEs' technological innovation and Enlightenment to China [J] Productivity Research, 2013,(1):136-139.

[4] Li Zhang. Research on SMEs' Independent Innovation of Japan [J] Journal of Theory, 2013, (7):185-188.

[5] Kai Hu. Concept and Connotation of Technology Innovation Policy[J] Proceedings of the 2012 International conference on management innovation and public policy, Vols1-6,p326-331,2012.

[6] Cullen, Julie Berry, Roger H Gordon. Taxes and entrepreneurial activity: Theory and Evidence for the US[J]. NBER Working Paper, 2002, 90(15):25-36.

[7] Han Pei. Research on Taxation Policy to Stimulate Corporate Technological Innovation of China[D] Northeast University of Finance, Master Thesis, 2012.

[8] Liqing Li. Research on the Effectiveness of Chinese R\&D Taxation Policy [J] China Soft Science, 2007, (7):115-120.

[9] Xiaolan Deng, Haiyan Tang. Analyze on the Incentive Effect of Taxation Policy to Corporate R\&D[J] Science and Technology Management Research, 2008,(7):490-493.

[10] Xiaoping Kuang, Jianhua Xiao. Integration of Taxation Policy to Cultivate Independent Innovation Ability of China [J] Contemporary Finance and Economics, 2008, (1):23-27.

[11] Daming Li, Zhengzhong Gong. International Reference to Consummate Chinese Taxation Policy of Independent Innovation [J] Study and Practice, 2006, (11):39-44.

[12] Zhiyun Zhao. Taxation Policy Adjustment to Promoting Corporate Independent Innovation [J] Taiyuan Science and Technology, 2006, (4):7-8. 
[13] Guofeng Ni. Reflect on Taxation Policy to Promoting Chinese SMEs' Technological Innovation [J] China Management Informationization, 2011, (7):28-30.

[14] Hongxiao Zhang, Bo Xiong. Taxation Policy to Promoting Corporate Technological Innovation-Based on Perspective of Internal Comparison [J] Science and Technology Progress and Policy, 2012, (22):140-142.

[15] Zhidong Zhang. Taxation Policy Choice of Hi-Tech Industry Development [J] China Audit, 2006, (8):46-48.

[16] Lan Zhao. Taxation Policy to Support Corporate Independent Innovation [J] Contemporary Economic Research, 2007, (2):59-63.

[17] Yuan Zhang. Taxation Support to Promoting Chinese SMEs' Independent Innovation [J] Finance and Accounting Monthly, 2010, (11):38-39.

[18] Yuehua Mei. Research on Taxation Policy and Tax Management System to Promoting Corporate Independent Innovation[D] Financial Science Institute of The Ministry of Finance, Doctoral Dissertation, 2012.

[19] Http://business. sohu.com/20110628/n311834016.shtml,2011-6-28.

[20] Jun Wen. The Role of Venture Capital in Innovation System of Silicon Valley [J] Global Outlook of Science and Economic, 2006, (10).

[21] Ping Gao. Practice and Thinking about Taxation Policy to Support Corporate Technological Innovation [J] Taxation Research, 2011,(5):77-80. 